N.K. Meshkov, S.F. Camasta,* and T.L. Gilbert Energy and Environmental Systems Division

March 1988

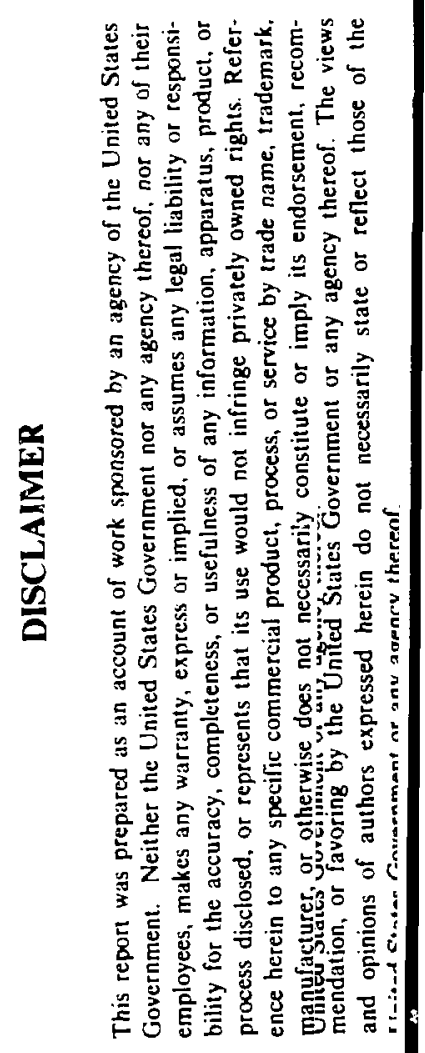

work sponsored by

U.S. DEPARTMENT OF ENERGY

National Low-Level Radioactive Waste Management Program

*Present address: Hinsdale South High School, 7401 Clarendon Hills Road, Darien, Illinois 60559 


\section{CONTENTS}

ABSTRACT $\ldots \ldots \ldots \ldots \ldots \ldots \ldots \ldots \ldots \ldots \ldots \ldots \ldots \ldots \ldots \ldots \ldots \ldots \ldots \ldots \ldots \ldots \ldots$

1 intRoduction $\ldots \ldots \ldots \ldots \ldots \ldots \ldots \ldots \ldots \ldots \ldots \ldots \ldots \ldots \ldots \ldots \ldots \ldots$

2 IDENTIFYING WASTE MANAGEMENT SYSTEM GOALS .............. 3

3 GENERAL APPROACH TO WASTE MANAGEMENT SYSTEM

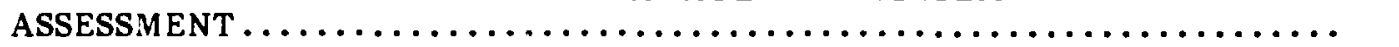

3.1 Components of a Waste Management System ................. 4

3.1.1 Types of Wastes Generated ........................ 4

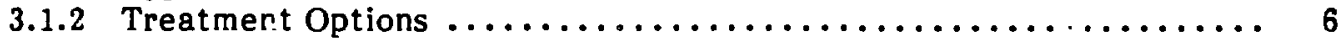

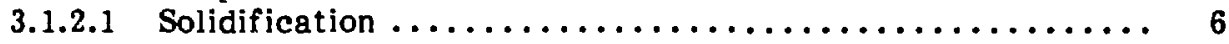

3.1.2.2 Mechanical Treatment ..................... 7

3.1.2.3 Dewatering .......................... 7

3.1.2.4 Decontamination ........................... 8

3.1.2.5 Chemical Methods ........................ 8

3.1.2.6 Biological Methods ....................... 8

3.1 .3 Packaging Options $\ldots \ldots \ldots \ldots \ldots \ldots \ldots \ldots \ldots \ldots \ldots \ldots \ldots \ldots \ldots \ldots \ldots \ldots$

3.1.3.1 Container Materials ...................... 9

3.1.3.2 High-Integrity Containers .................... 10

3.1.3.3 Other Considerations $\ldots \ldots \ldots \ldots \ldots \ldots \ldots \ldots \ldots \ldots \ldots \ldots \ldots \ldots 11$

3.1 .4 Storage Options $\ldots \ldots \ldots \ldots \ldots \ldots \ldots \ldots \ldots \ldots \ldots \ldots \ldots \ldots \ldots \ldots \ldots \ldots \ldots \ldots 11$

3.1 .5 Transportation Options .......................... 11

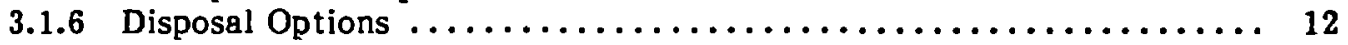

3.2 Benefit-Cost-Risk Analysis $\ldots \ldots \ldots \ldots \ldots \ldots \ldots \ldots \ldots \ldots \ldots \ldots \ldots \ldots \ldots \ldots \ldots$

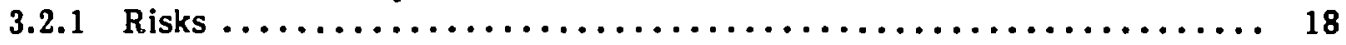

3.2 .2 Costs $\ldots \ldots \ldots \ldots \ldots \ldots \ldots \ldots \ldots \ldots \ldots \ldots \ldots \ldots \ldots \ldots \ldots \ldots \ldots \ldots \ldots \ldots \ldots 19$

4 APPLICABILITY OF THE REGINALT SYSTEM $\ldots \ldots \ldots \ldots \ldots \ldots \ldots \ldots \ldots \ldots \ldots$

4.1 REGINALT System as an Overall Assessment Tool for Waste

Management .................................. 20

4.2 Recommended REGINALT Modifications ................... 22

4.3 Recommendations for the REGINALT Systems Guide . . . . . . . . . . . 23

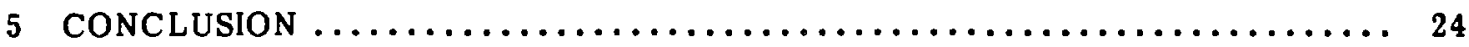

REFERENCES $\ldots \ldots \ldots \ldots \ldots \ldots \ldots \ldots \ldots \ldots \ldots \ldots \ldots \ldots \ldots \ldots \ldots \ldots \ldots \ldots \ldots$

FIGURES

1 Cost-Risk Plot for Hypothetical Waste Management Alternatives .......... 16

2 Cost vs. Risk for Several Waste Management Options . . . . . . . . . . . 17

3 REGINALT as an Integrated System $\ldots \ldots \ldots \ldots \ldots \ldots \ldots \ldots \ldots \ldots \ldots \ldots \ldots$ 
TABLES

1 Waste Management System Options

2 Disposal and Treatment Options Considered by Foutes and Queenan, 1987 


\title{
ASSESSING WASTE MANAGEMENT SYSTEMS USING REGINALT SOFTWARE
}

by

N.K. Meshkov, S.F. Camasta, and T.L. Gilbert

\begin{abstract}
A method for assessing management systems for low-level radioactive waste is being developed for the U.S. Department of Energy. The method is based on benefit-cost-risk analysis. Waste management is broken down into its component steps, which are generation, treatment, packaging, storage, transportation, and disposal. Several different alternatives available for each waste management step are described. A particular waste management system consists of a feasible combination of alternatives for each step. Selecting an optimal waste management system would generally proceed as follows: (1) qualitative considerations are used to narrow down the choice of waste management system alternatives to a manageable number; (2) the costs and risks for each of these system alternatives are evaluated; (3) the number of alternatives is further reduced by eliminating aiternatives with similar risks but higher costs, or those with similar costs but higher risks; (4) a trade-off factor between cost and risk is chosen and used to compute the objective function (sum of the cost and risk); and (5) the selection of the optimal waste management system among the remaining alternatives is made by choosing the alternative with the smallest value for the objective function. The authors propose that the REGINALT software system, developed by EG\&G Idaho, Inc., as an aid for managers of low-level commercial waste, be augmented for application to the management of DOE-generated waste. Specific recommendations for modification of the REGINALT system are made.
\end{abstract}

\section{INTRODUCTION}

The U.S. Department of Energy (DOE) is involved in many activities that generate large quantities of low-level radioactive waste. More than 2 million cubic meters have already been disposed of, and the disposal rate has been steadily increasing. The total amount of DOE low-level waste buried in 1985, for example, was about $\mathbf{0 . 1 2}$ million cubic meters (Oak Ridge National Laboratory, 1986).

Low-level waste is of ten treated, packaged, and/or stored prior to disposal. All the steps taken in managing the waste (i.e., generation, treatment, packaging, storage, 
transportation, and disposal) constitute a waste management system. An optimal waste management system should provide an adequate margin of public, occupational, and environmental safety in a cost-effective manner over both the short and long term. To accomplish this, DOE has initiated a systems approach for managing waste (Logan, 1987a). The approach consists of tailoring the methods used for managing waste to suit the quantities and characteristics of the waste, while taking into account the characteristics of the disposal site. It requires methods and procedures for assessing the performance of any waste management system. This report addresses this need.

The task discussed in this report is to provide methods and procedures that will enable managers to review an entire waste management system from generation to disposal in order to assess its performance. More specifically, the aim is to develop an efficient and practical method for comparing costs, benefits, risks, and trade-offs at all stages of waste management.

The first step in developing such a method is identification of overall waste management system goais, which is addressed in Sec. 2. The general approach to the methodology of waste management system assessment is presented in Sec. 3, with the components of a waste management system being identified and briefly described in Sec. 3.1, and the method of benefit-cost-risk analysis and how it applies to waste management being discussed in Sec. 3.2.

A model named REGINALT was recently developed at EG\&G Idaho, Inc., to allow managers in the commercial sector to analyze the various treatment and disposal options available for handling a wide variety of waste streams. This model is reviewed here with respect to its potential usefulness for assessing DOE waste management systems. The model is well designed and simple to use, and can easily be augmented to provide a very useful tool for DOE waste managers. The REGINALT system and recommendations for its modification are discussed in Sec. 4; Sec. 5 contains the concluding remarks. 


\section{IDENTIFYING WASTE MANAGEMENT SYSTEM GOALS}

The goal of a waste management system is to dispose of low-level radioactive waste in a systematic, safe, and economical manner. The performance objectives that must be met by a waste management system are (1) protection of public health and safety, (2) protection of occupational health and safety, and (3) management of low-level waste in an environmentally sound manner. Compliance with basic radiation protection criteria for members of the general public and for radiation workers is of primary importance. Such compliance must be achieved without regard to cost. In addition, detrimental effects must be reduced to levels that are as low as reasonably achievable (ALARA). Cost becomes a consideration in judging what further reductions are "reasonably achievable."

A number of federal (DOE, U.S. Environmental Protection Agency [EPA], U.S. Department of Transportation [DOT], and U.S. Nuclear Regulatory Commission [NRC]) and state guidelines and regulatory requirements address more specific performance objectives derived from basic radiation criteria. Examples of such objectives are radiation dose limits for members of the general public and radiation workers, dose limits outside of packages containing radioactive waste, and water and air contamination limits. The waste management system must satisfy all these performance objectives.

In addition, nonradiological hazards may exist because of the presence of various toxic, flammable, or explosive substances in the waste. Reduction of nonradiological detrimental effects to acceptable limits is another important performance objective of waste management systems. 


\section{GENERAL APPROACH TO WASTE MANAGEMENT SYSTEM ASSESSMENT}

\section{$\therefore$ COMPONENTS OF A WASTE MANAGEMENT SYSTEM}

The waste management system comprises all steps of waste management (i.e., generation, packaging, storage, processing, transportation, and disposal). A number of options are available for each of the steps. The types of wastes generated and the options for the various steps are summarized in Table 1 and briefly described below.

\subsubsection{Types of Wastes Generated}

Wastes generated by DOE have been classified using a computerized reporting system called Solid Waste Information Management System (SWIMS), which divides lowlevel waste into the following six broad types based on radiological properties (Oak Ridge National Laboratory, 1984):

1. U-Th. Waste containing naturally occurring uranium and thorium, such as uranium ore or depleted uranium.

2. Fission Products. Waste contaminated with $B / Y$ radionuclides resulting from nuclear fission.

3. Induced Activity. Waste contaminated with $\mathrm{B} / \mathrm{Y}$ radionuclides resulting from neutron activation.

4. H-3. Tritium-contaminated waste.

5. Alpha. Waste with a contamination, including transuranic waste, but with activity concentrations less than $100 \mathrm{nCi} / \mathrm{g}$.

6. Other. Waste not fitting any of the other categories.

The SWIMS classification system also defines six categories of waste based on nonradiological properties: (1) biological waste, (2) contaminated equipment, (3) decontamination debris, (4) dry soljds, (5) solid sludge, and (6) not classified.

The waste characterization approaches currently in use are not sufficiently detailed for selecting appropriate processing options (Bohrer and Dalton, 1987; Logan, 1987a,b; Rodgers et al., 1987). Waste characterization for efficient waste management should enable a determination of waste acceptability with respect to each component of the waste management system (e.g., explosive material cannot be incinerated and highly acidic wastes should not be packaged in steel drums). Characterization should also be sufficiently detailed to estimate the risk to radiation workers and the general public with enough accuracy to discriminate between alterratives for each system component and to estimate costs for mitigating the risk associated with each alternativa. 
TABLE 1 Waste Management System Options

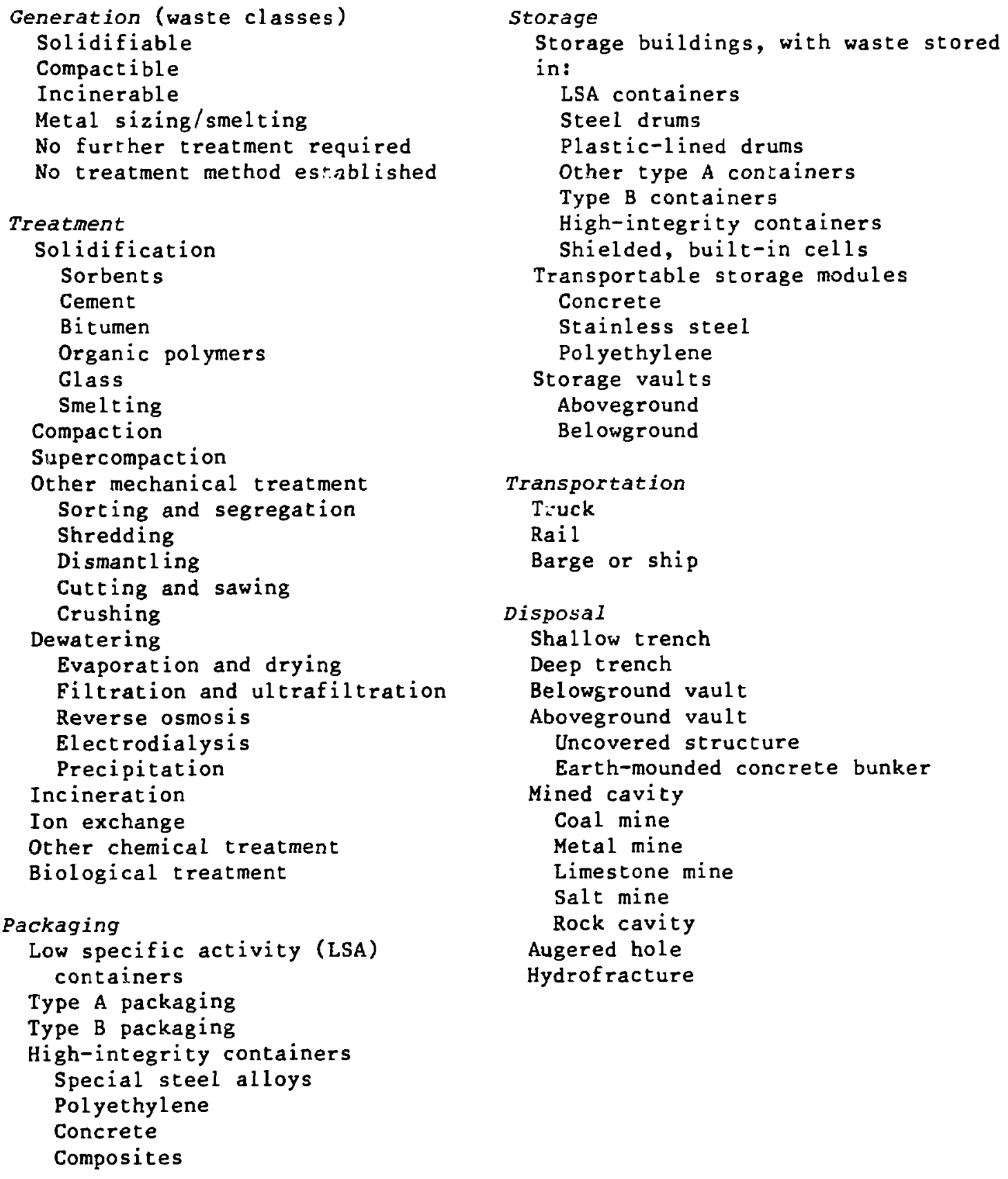




\subsubsection{Treatment Options}

The waste may be routinely treated before disposal. For example, it may be compacted, incinerated, or shredded. If it contains aqueous material, it may undergo evaporation, flocculation, ion exchange, solidification, and/or filtration. Liquid wastes and some others may need to be stabilized. Cement, polymers, bituminous compounds, and glass have been used as immobilizing materials.

Low-level waste may undergo treatment to reduce its volume, reduce its toxic and biological hazards, improve its physical stability, and reduce its radiological hazard by curtailing its leachability. Treatment categories identified in a 1985 survey of U.S. commercial nuclear power plants include solidification; mechanical treatment; dewatering; decontamination; various thermal, physical, and chemical processes; and biological methods (Jolley and Rogers, 1987). These treatment options are briefly described in Secs. 3.1.2.1-3.1.2.7.

\subsubsection{Solidification}

Solidification is appropriate for immobilizing liquid wastes and for encapsulating semisolid and solid wastes. It improves the physical stability of the waste and reduces the leachability of some of its toxic constituents. For example, ash resulting from waste incineration may contain leachable heavy metals and may therefore require solidification (Bohrer and Dalton, 1987).

A chemical process sometimes used for treating liquid waste streams is addition of sorbents to the basic solidification agents. These sorbents can be either natural or synthetic inorganic materials or organic materials, such as super slurpers. Sorbents effectively immobilize residual free liquids; when used in conjunction with solidification agents, they can contribute to volume reductions of up to $20 \%$.

Solid waste can be immobilized by placing the waste in a liquid or semiliquid material that solidifies after the waste is added. The four most commonly used immobilizing materials are discussed below.

- Cement. Cement is commonly used for waste immobilization (Dougherty and Colombo, 1985; Arora and Dayal, 1986; Malek and Roy, 1987). It is the most economical material to use, and it is also structurally sound. Leaching from cement has been observed; however, adjusting the water-to-cement ratios and using additives (e.g., fly ash and slag) reduces leaching and improves engineering characteristics.

- Bitumen. Bitumen is finding increased application in the waste management field (Snellman and Uotila, 1984; Dougherty et al., 1986; Mattus and Kacamarsky, 1987). Experiments indicate that radionuclides leach less from bitumen than from concrete. However, bitumen tends to swell and/or deform with increased temperature, compression, and irradiation. It is also attacked by 
microorganisms. Nonetheless, its plasticity could still be advantageous.

- Organic Polymers. Various polymers could be appropriate as solidifying agents (Franz and Colombo, 1985; Dougherty et al., 1986; Nielson et al., 1987). Their overall suitability is based on low permeability to water, high plasticity, and favorable economies. Problems have been experienced at high irradiation levels and high waste loadings. The potential for microbial attack also exists.

- Glass. Glass has been used extensively to immobilize high-level radioactive waste (Armstrong and Klinger, 1984; Dougherty and Colombo, 1985; Okamoto et al., 1986). Soda-lime glasses, rather than borosilicate glasses, have been tested with low-level waste. Low leachability is an advantage. If the waste were to be incinerated, vitrification would be a one-step process. A cement glass was tested recently, with favorable results.

Several varieties of these immobilizing materials have been used successfully for low-level waste management (e.g., Dougherty and Colombo, 1985; Dougherty et al., 1986; Franz et al., 1986; Illinois Dept. of Nuclear Safety, 1986; Sturm et al., 1986). Smelting has also been used for immobilizing and reducing the volume of the waste.

\subsubsection{Mechanical Treatment}

The basic objective of mechanical treatment is volume reduction, which can be accomplished in several ways. Shredding is used for some solid wastes (e.g., paper, cloth, plastics, or light metal) as a pretreatment before compaction or incineration. Dismantlement, cutting, or sawing is used to reduce the void fraction of the waste. Crushing, compaction, and supercompaction are also used. Compactors are available in a variety of sizes and designs. Standard compactors achieve volume reductions of two to six times. Supercompactors can accept waste already compacted and stored in 55-gallon drums. Very high pressures are used to further crush the waste, reducing the volume up to 15 times (Gillins and Larsen, 1987). Another type of mechanical treatment is sorting and segregation.

\subsubsection{Dewatering}

Removing water stabilizes the waste to some degree and reduces the waste volume. Dewatering processes include evaporation, drying, centrifugation, filtration, ultrafiltration, reverse osmosis, electrodialysis, precipitation, and other solids-handling methods. 


\subsubsection{Decontaminaťón}

This category comprises mechanical and ultrasonic cleaning, chemical, and electrolytic polishing techniques.

\subsubsection{Chemical Methods}

Radioactive materials dissolved in a liquid waste stream can be removed from it by ion-exchange mechanisms in which ions of the same charge are interchanged between an electrolyte solution and an ion-exchange medium. Ion-exchange resins, which are insoluble high-molecular-weight polyelectrolytes, are commonly used as ion-exchange media. Resin types exist for both positive and negative ion exchange. Resins are commonly used in conjunction with filters and demineralizers. Another ion-exchange medium is a natural clay zeolite, which is particularly effective for removing strontium and cesium (Maestas, 1987). Two important chemical methods used for volume reduction are discussed below.

- Incineration. Incineration is an effective way to reduce the chemical and biological hazards of the waste. Although it greatly reduces the waste volume, a corresponding increase occurs in the activity concentration. Therefore, the resulting waste ash usually requires solidification not only to stabilize it, but also to prevent dispersion. A variety of currently employed incineration techniques are described in several reports (e.g., EG\&G ldaho, Ine., 1984; Stone and Webster, 1985; Bohrer and Dalton, 1987).

- Oxidation-Reduction. Oxidation and reduction processes can also be effective in volume reduction. A wet-oxidation volume reduction and solidification (WOX) process has been described recently (Petersson and Hedin, 1987). Hydrogen peroxide is used to oxidize and decompose ion-exchange resin material. Volume reduction is high.

\subsubsection{Biological Methods}

The results of a 1985 survey of operators of commercial U.S. nuclear power plants revealed that none were using, or were considering using this method for low-level waste treatment (Jolley and Rodgers, 1987).

\subsubsection{Packaging Options}

The waste packaging options available to the generator vary with the characteristics of the low-level waste and the regulations governing that waste. The packaging option is determined to some degree by the final form of the waste. For example, bulky wastes with low activity may be incinerated and the ash disposed of in metal containers. In general, the waste must be compatible with its package 
(i.e., low-pH wastes should not be disposed of in carbon-steel drurns). Packaging regulations established by DOE (Order 1540.2), NRC (Title 10 CFR Part 71), and DOT (Title 49 CFR Parts 173 and 178) also affect the choice of packaging option.

DOE packaging designs must meet safety criteria at least as stringent as the standards prescribed by NRC in Title $10 \mathrm{CFR}$ Part 71. The general standards for all packages are listed in Part 71, Sec. 43. Part 71, Sec. 45, lists lifting and tie-down standards, and Part 71 , Sec. 47 , lists an external radiation standard of $\leq 200 \mathrm{mrem} / \mathrm{h}$. Subparts D and E list criteria for packaging approval, and Subpart F lists package and special form tests.

The DOT regulations in Title 49 CFR Part 173, Secs. 401-478, pertain to general design requirements, waste classification, and tests required for package approval. Part 178 gives shipping container specifications. Part 178, Sec. 401 , states that "the requirements prescribed in this subpart are in addition to, but not in lieu of $10 \mathrm{CFR}$ Part 71."

The DOT uses three categories for classifying packaging of radioactive material. The first of these consists of limited quantities of radioactive instruments and articles of low specific activity. These low-specific-activity wastes must be packed in strong, tight containers. High-quality industrial grade packaging is normally considered adequate to provide protection against the unintentional release of contents under normal transportation conditions. Types "A" and "B" are the other categories. Type A packaging should be adequate to prevent ioss or dispersal of contents and maintain shielding under normal transport conditions; water spray, free drop, corner drop, compression, and penetration tests are required (49 CFR 173.403 and 173.465). Type $B$ packaging must be adequate for certain accident conditions, in addition to those mentioned above. Tests are required for water immersion, free drop, puncture, and hea: (49 CFR 173.467 and 173.413; a) o $10 \mathrm{CFR} 71,71.51,17.73$ ).

\subsubsection{Container Materials}

Traditional containers for low-level waste disposal have included standard steel drums and metal and wooden boxes. More specifically, the 55-gallon (208-liter) cylindrical drum has been used extensively for waste aisposal since the nuclear industry's inception. Improved containers potentially enhance any disposal system by reducing reliance on other system components and by providing a final barrier to an intruder (Otis, 1986). Several materials are being utilized in traditional and improved radwaste disposal containers.

- Carbon-steel is economical and traditionally used, but subject to corrosion and failure.

- Stainless steel is corrosion resistant and structurally sound, but expensive.

- Polyethylene is fairly economical and not subject to corrosion, but has several disadvantages, including flammability. 
- Concrete is economical, durable, and corrosion resistant, but has several problems, including the great weight of large containers.

- Other polymers as well as composite materials are being investigated.

Factors to be considered in selecting container materials are cost, strength, corrosion resistance, general chemical inertness, ease of handling, and permeability to water.

\subsubsection{High-Integrity Containers}

High-integrity containers (HIC) may be used instead of, or in addition to, immobilizing materials, depending on the waste type. Such containers are designed for underground burial and must ensure containment for 300 years. They must be easy to fabricate and reasonable in cost. Storage and handling prior to burial must be considered in their design. They must pass drop tests and other structural support tests, as well as be stable in the presence of chemicals and radioactivity (McCoy et al., 1987).

A steel-fiber, polymer-impregnated concrete $\mathrm{HIC}$, designed by Chichibu Cement Co., Ltd., has NRC approval for disposal of ion-exchange media, filter media, solid wastes, filter cartridges, solidified resins, and sludges. The polymer reduces the permeability of the concrete. The strength and toughness of these containers exceed those of plain concrete. Both 55- and 110-gallon containers have been designed (Johnson et al., 1987).

An HIC composed of duplex stainless steel and Ferralium alloy 225 is also approved by NRC. This container exhibits excellent corrosion resistance, even at low pH. Multiple sizes are available from Pacific Nuclear Systems (Johnson et al., 1987).

Also under development by Chem-Nuclear Systems is a hig.1-density, cross-linked polyethylene HIC proposed for use with bead and powdered ion-exchange resins, filter sludges, solid wastes, fibrous filter media, and solidified waste forms. Fifty-five-gallon drums and 6-ft-diameter by 6-ft-high cylinders have been designed (Johnson et al., 1987).

An HIC described as converient, economical, and in compliance with NRC and state requirements consists of an inner layer of polyethylene and outer casing of fiberglass reinforced plastic. It is available in sizes ranging from $7 \mathrm{ft}^{3}$ to $200 \mathrm{ft}^{3}$ (Lowenberg and Shaw, 1987).

Another HIC has been proposed that has a stainless steel shell and a low-density polyethylene lining that is rotomolded into the shell. Both corrosion resistarice and structural stability are promised by its fabricators, LN Technologies. Sizes start at 55 gallons (McCoy et al., 1987). 


\subsubsection{Other Considerations}

Although round containers are commonly used, square containers have been recommended as being more efficient in terms of storage space and therefore less costly. The conventional $7.5-\mathrm{ft}^{3}$ (55-gallon) drum occupies about the same amount of space as the 9.5- $\mathrm{ft}^{3}$ (71-gallon) square drum (Greaves, 1987). Transportable concrete modules have been proposed for storage and permanent disposal; in this case, the waste packages are placed in the modules and grouted (Mallory, 1987).

\subsubsection{Storage Options}

Low-level radioactive waste may be stored for several reasons. Short-term storage (about five years or less) may be used to provide operational flexibility in waste management (e.g., to accumulate enough material for efficient treatment, packaging, or shipping). It may also be used to allow short-lived radionuclides to decay to lower activity concentration levels, thus permitting more economical disposal of the waste. Long-term storage (up to $\mathbf{5 0}$ years) followed by permanent disposal may be used to allow somewhat longer lived isotopes to decay. Long-term storage may also be employed as an interim disposal method for certain wastes until an appropriate permanent disposal facility becomes available (Van Kote, 1982; Carter and Rao, 1985; Siskind et al., 1985; Emmett, 1987). The type of storage facility and packaging reguired will depend on the physical, chemical, and radiological characteristics of the waste. Some waste may have to be treated (e.g., solidified or incinerated) before storage. Some of the storage facilities currently used by DOE are described in Nelson and Divine (1980), Siskind et al. (1985), Emmett (1987), and Mallory (1987).

Storage buildings with shielded storage cells are commonly used. Transportable, on-site, concrete storage modules with various diameters have also been used. The unit cost of these modules is favorable, and they can be procured as needed (Mallory, 1987).

An interim storage demonstration program has been developed at the Oak Ridge Gas Diffusion Plant. Existing vaults that protect waste containers from direct weather effects are being used. The site is secured and administratively controlled. The waste containers being used are DOE 17C 55-gallon drums, plastic liners in DOT 17H 55-gallon drums, and B-25 steel boxes. Container corrosion, gas generation, and effluent release are being monitored (Emmett, 1987). Potential problems arising during extended storage are discussed in Siskind et al. (1985).

\subsubsection{Transportation Options}

Waste may be transported between any two steps in the waste management process (e.g., between generation and storage, between storage and treatment, and between treatment and disposal). The two modes most likely to be employed are truck and rail transport. Water transport may be an option over longer distances if routes are accessible to waterways. If the surface dose rate on the waste package exceeds regulatory requirements, shielded vans or shipping casks must be used to shield the waste during transport. A variety of shipping casks providing different amounts of shielding are 
available for rent, lease, or purchase (Sciacca et al., 1986). The Freight Network Modeling System is also available (Argonne National Laboratory, 1985).

DOT has promulgated regulations regarding transport of radioactive materials in Title 49 of the Code of Federal Regulations. Part 174, Secs. 700, 715, and 750, gives details concerning rail transport; Part 175, Secs. 700-702, concerning air transport; Part 176, Secs. 700-715, concerning water transport;, and part Part 77 concerning highway transport. The regulations specify such thirigs as the amount of radiation that can be emitted from packages, the required labeling, distances the packages must be from humans and other cargo. Packaging is not specified, other than in a general way.

Computer codes are available for those choosing among the transportation options. TRANSNET, developed at Sandia National Laboratories, contains a network of transportation models, including RADTRAN III, INTERSTAT, and FRIRATE. As of March 1987, RAILSTAT, BARGESTAT, StateGEN, and StateNET were being developed. WASTES II, RADCOM, and TRANSIT should be available for TRANSNET users (Cashwell, 1987). The Freight Network Modeling System is also available (Argonne National Laboratory, 1985).

\subsubsection{Disposal Options}

Six disposal sites are currently used by DOE: Hanford Reservation in Washington, Idaho National Engineering Laboratory in Idaho, Los Alamos National Laboratory in New Mexico, Nevada Test Site in Nevada, Oak Ridge National Laboratory in Tennessee, and Savannah River Site in South Carolina. Most wastes generated at these sites are disposed of on site. Small quantities of waste generated at other DOE sites are shipped to these sites for disposal. The western sites are arid, and the two sites in the East (Oak Ridge and Savannah River) are humid.

Alternatives for disposal of low-level waste can be divided into two basic categories: shallow land burial and greater confinement disposal. Shallow land burial is

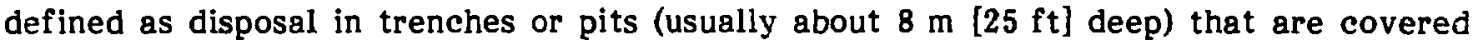
with a cap of clay and/or topsoil. Greater confinement disposal is defined as "a techinique for disposal of waste that uses natural and/or engineered barriers which provide a degree of isolation greater than that of shallow land burial but possibly less. than that of a geologic repository" (DOE Order 5820.2). Greater confinement disposal can in turn be subdivided into two groups: above-grade confinement and below-grade confinement.

Above-grade confinement generally refers to containment cells (wastes and their protective envelope) that lie above the surrounding grade. Earth-covered tumuli and aboveground concrete vaults are the two basic designs. In the earth-covered tumulus option, the wastes are placed above grade and are surrounded by a structure and/or backfill. This system is ultimately covered with layers of geologic materials such as soil, clay, sand, and/or rocks. An aboveground concrete vault would differ from an earthcovered tumulus in that it would not have a cover of geologic materials. 
A number of options can be considered for below-grade confinement: deep trenches, augered shafts, below-grade concrete structures, underground mines, rock cavities, and hydrofractures. Deep trenches are excavations that differ from shallow land burial inainly in the depth at which wastes are buried. Trenches as deep as 15-20 m (50-65 ft) have been considered. Hanford is currently disposing of waste at depths up to $17 \mathrm{~m}(55 \mathrm{ft})$. Augered shafts are holes bored in the earth. The length-to-diameter ratio and the depth are chosen so that the wastes are not likely to be penetrated by rain and snowmelt, roots, animals, and human intruders. The below-grade concrete disposal cell generally has walls that are formed of poured reinforced concrete. Situated completely below grade, the cell may have a concrete floor and cover. Existing mines may be used for waste disposal, or rock cavities may be excavated solely for the purpose of waste disposal. Hydrofracturing involves mixing the wastes with cement and injecting the resulting grout slurry into horizontal fractures previously induced into rock by highpressure injection of water. The hydrofractures may be at depths as great as $1000 \mathrm{~m}$ $(3300 \mathrm{ft})$ below the surface.

The various disposal options available are described in detail in a number of reports (e.g., Dames and Moore, 1985; Gilbert et al., 1986; Rogers and Associates, $1987 \mathrm{a})$.

\subsection{BENEFIT-COST-RISK ANALYSIS}

A particular waste management system consists of a feasible combination of alternatives for each waste management step. Qualitative considerations are used to narrow down the choice of system alternatives to a manageable number. For example, certain types of waste require a particular treatment option. Thus, waste containing biological material may have to be incinerated and the resulting waste ash may have to be solidified. On the other hand, paper waste may be either incinerated or compacted to reduce its volume. The choice of packaging may depend on the treatment option selected. After a small number of waste management alternatives have been selected for further consideration, a more quantitative procedure is needed to narrow down the choices even further.

Methods for selecting an optimal waste disposal system should be explicit and quantitative, allowing for clear separation between technical and policy issues. An adaptation of the benefit-cost-risk analysis recommended by the International Commission on Radiological Protection (ICRP) for optimization of radiation protection in the design of installations meets both these requirements (1CRP, 1983) and is described below.

Selection of a waste management system alternative is based on the principle that the alternative having the greatest net benefit should be chosen. The net benefit for alternatives that provide different degrees of radiation protection is defined in ICRP (1983) as:

$$
B=V-P-(X+Y)
$$


where:
$B=$ net benefit,
$V=$ gross benefit,
$\mathbf{P}=$ production costs,
$X=$ radiation protection costs (which, in the present context, may be equated to the total monetary cost of managing a given quantity of waste), and
$Y=$ risks (which, in the present context, may be equated to the sum of all detrimental effects, converted to monetary units, of managing a given quantity of waste).

The gross benefit and production costs are incurred as a result of the activities that produce the waste. For the most part, waste managers are not concerned with balancing the gross benefits associated with production of the waste against the costs and risks of waste management. On the other hand, waste minimization activities are playing an increasingly important role in waste management (Lane and Boggs, 1987; Kane, 1987; Blasdel et al., 1987). Such waste minimization activities may include recycling, segregation of hazardous and nonhazardous wastes, substitution of nonhazardous process materials for hazardous ones, and process modification. Although waste minimization activities should be included in waste management system assessment, it is not expected that these activities will significantly affect gross benefits. Therefore, the alternative for which the net benefit is largest will be the alternative for which the sum of waste management costs and risks is the smallest. This sum is defined as the objective function U:

$$
\mathrm{U}=\mathrm{X}+\mathrm{Y}
$$

The risks include detrimental effects from exposure of workers and members of the general public to radiation from radionuclides at all waste management steps, industrial accidents, and other socioeconomic and environmental effects associated with radioactive waste management. They are calculated in appropriate units (e.g., in dose equivalent units [rems or sieverts] for the effects of radiation and in health effects [illnesses and fatalities] for industrial accidents). A trade-off factor converts the risks to monetary units. For example, the risk from exposure of the general population to radiation from radionuclides in the waste will be:

$$
Y_{R}=\alpha R
$$

where:

$$
\begin{aligned}
Y_{R} & =\text { radiological risk in dollars for the general population, } \\
\alpha & =\text { trade-off factor for the collective dose (in } \$ / \text { person-rem), and }
\end{aligned}
$$


$R=$ collective, time-integrated, effective dose equivalent received by the general population from radionuclides in the waste (in personrem).

The trade-off factor is needed to convert the units associated with different detrimental effects to a common unit so that the detrimental effects can be aggregated into a total risk and the total cost and total risk can be summed to obtain a value for the objective function $U$. The size of the trade-off factor is a measure of the level of societal concern attached to a particular risk. A large trade-off factor indicates a willingness to pay lot for mitigating a particular risk; a small trade-off factor shows that less importance is attached to that risk. In general, the trade-off factor changes as the magnitude of risk changes (i.e., the trade-off factor is a function of risk $\alpha=\alpha[R]$ ), making Eq. 3 nonlinear with respect to $R$. However, most risk estimates possible at the present time are not accurate enough to justify such refinements. For most practical purposes, a can be assumed to be a constant.

Calculating $R$ is a technical matter, whereas assigning a value to $a$ is a policy matter. Thus, Eq. 3 provides for clear separation between technical and policy issues (as do similar equations for other detrimental effects).

The number of waste management alternatives to be considered can be further reduced by looking at costs and risks alone, prior to selecting a trade-off factor. For example, if there are a number of alternatives with the same costs but different risks, the alternative with the lowest risk is the obvious choice. Similarly, among alternatives with similar risks but varying costs, the least costly alternative should be chosen.

A more general result can be obtained by representing all feasible alternatives on a graph, with the cost plotted along the horizontal axis and the risk along the vertical axis. Such a graph is shown in Fig. 1 for hypothetical waste management alternatives. The most desirable alternatives lie on a curve concave upward (solid curve passing through the circled points). The alternatives above this curve are less desirable than the circled alternatives, regardless of trade-off factors. This result can be explained as follows. For a particular trade-off factor $\alpha$, Egs. 2 and 3 can be rewritten as:

$$
\mathrm{R}=\frac{\mathrm{U}}{\alpha}-\frac{\mathrm{X}}{\alpha}
$$

For a given value of the objective function U, Eq. 4 is a straight line on the cost-risk plot. The slope of this straight line is $-1 / \alpha$, and the $y$ intercept is $U / \alpha$. These straight lines are shown as dashed lines in Fig. 1 for the same trade-off factor a and different objective functions $U$. For this trade-off factor, the best choice is the alternative with the smallest objective function, that is, the one represented by the dashed line tangent to the solid curve. This argument can be repeated for other values of trade-off factors, leading to selection of the alternatives lying on the solid curve. Selection of optimum alternative from among the circled alternatives is a policy decision based on the tradeoff factor value chosen.

Figure 2 is a similar plot of waste management alternatives considered by Foutes and Queenan (1987). It is presented here to illustrate how this type of analysis can be applied to realistic situations. Foutes and Queenan considered 10 disposal options that 


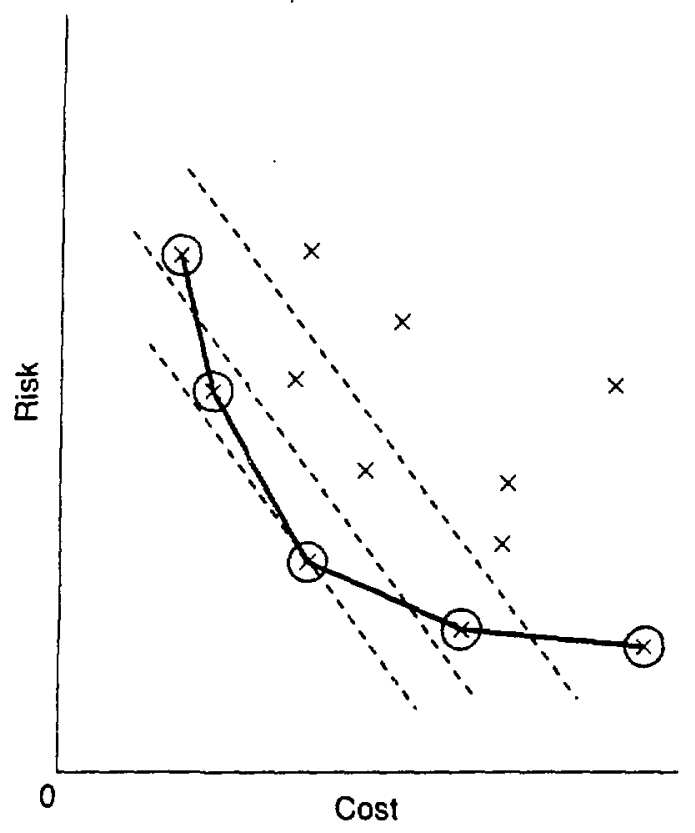

FIGURE 1 Cost-Risk Plot for Hypothetical Waste Management Alternatives

ranged from a regulated sanitary landfill to more stringent options such as conerete canisters and an earth-mounded concrete bunker. For each disposal option, several treatment and packaging suboptions were considered (Table 2). In Fig. 2, the cost of each option 'plotted horizontally) includes packaging, transportation, treatment, and burial of the total volume of commercial waste generated in the United States over a 20-year period (1985-2004). The estimated population risk (plotted vertically) includes statistical fatal cancers and genetic effects expected to occur over a 10,000-year period, The five most desirable alternatives, which are circled and numbered, and connected by a solid line, are (1) sanitary landfill, with the waste buried in its original form; (2) shallow land burial of untreated waste; (3) shallow land burial of untreated class $A$ and $B$ waste, but with improved shallow land burial for the rest; (4) shallow land burial for untreated class $A$ waste, but with improved shallow land burial for classes $B$ and $C$; and (5) shallow land burial for classes $A$ and $B$, but with improved shallow land burial for class $C$, with all the waste incinerated and solidified. Choosing alternative (1) over the other alternatives implies a very small value for the trade-off factor a (i.e., a large increase in risk is associated with a small decrease in cost). A slight increase in a will lead to alternative (3); alternatives (4) and (5) correspond to a somewhat larger $\alpha$. The uncertainties in the cost and risk estimates were not available and are not shown in Fig. 2. If the uncertainties had been included, it is very likely that many of the alternatives would have become indistinguishable.

The various risks and costs that should be taken into consideration in constructing an objective function for different waste management alternatives are described in the following sections. 


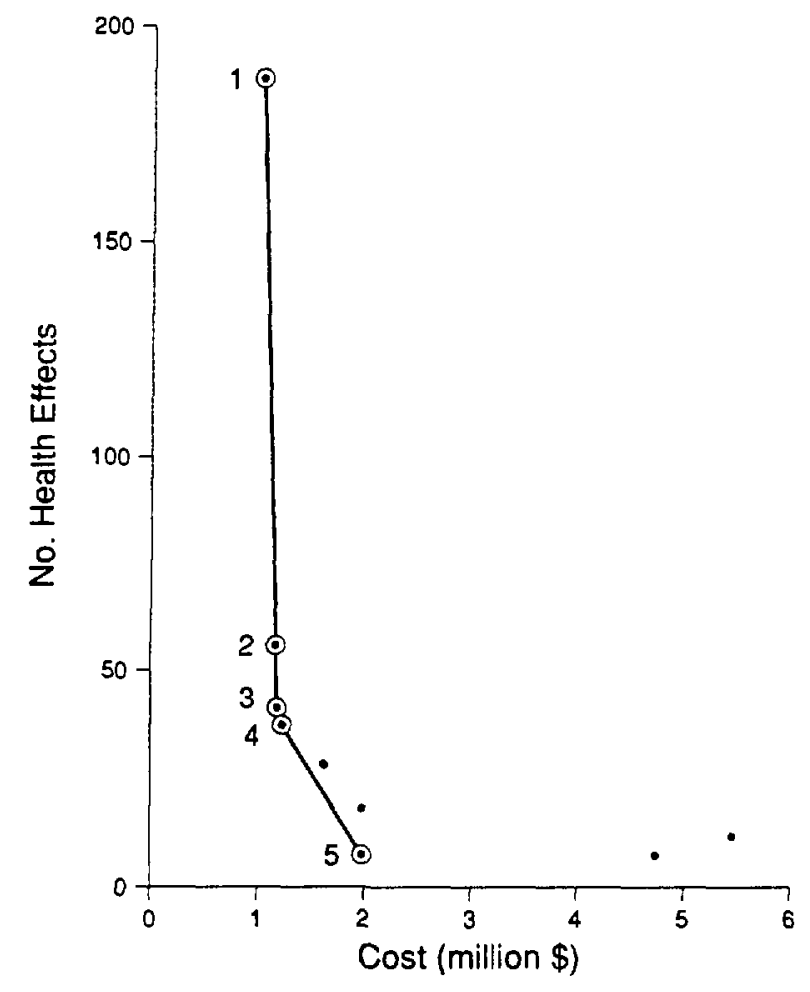

FIGURE 2 Cost vs. Risk for Several Waste Management Options (Source: Foutes and Queenan, 1987)

TABLE 2 Disposal s.nd Treatment Options Considered by Foutes and Queenan, 1987

\begin{tabular}{ll}
\hline \multicolumn{1}{c}{ Options } & Treatment Options \\
\hline $\begin{array}{l}\text { Disposal in a regulated sanitary landfill } \\
\text { Shallow land disposal }\end{array}$ & $\begin{array}{l}\text { Packaged as generated } \\
\text { Solidified } \\
\text { Improved shallow land disposal } \\
\text { Combination of shallow land disposal and } \\
\text { improved shallow land disposal }\end{array}$ \\
$\begin{array}{l}\text { Disposal at intermediate depths } \\
\text { Packaged in high-integrity } \\
\text { container }\end{array}$ \\
$\begin{array}{l}\text { Disposal in hydrofractures } \\
\text { Disposal in concrete canisters } \\
\text { Disposal in an earth-mounded concrete bunker }\end{array}$ \\
\hline
\end{tabular}




\subsubsection{Risks}

The harmful effects resulting from exposure to ionizing radiation have been identified and, when possible, quantified in ICRP (1983, 1984). Controlling these detrimental effects may introduce other harmful effects not necessarily caused by radiation. Nonradiological detrimental effects may be caused, for example, by hazardous materials present in mixed waste. Thus, both radiological and nonradiological risks should be included in assessments of waste management systems.

Radiological detrimental effects include (1) cancer, (2) hereditary effects in descendants of exposed persons, (3) physiological damage (e.g., erythema of the skin and opacification of the eye lens), and (4) effects on children exposed in utero. Physiological damage is insignificant for the exposure levels that can reasonably be expected to occur from low-level waste management. Cancer, hereditary effects, and in utero effects are assumed to be proportional to an appropriately defined radiation dose based on the linear no-threshold hypothesis used for assessing the effects of low-level radiation. The collective effective dose equivalent commitment as defined by the ICRP (1984) -- of ten referred to in this report as "dose" for brevity -- is used as a common measure to aggregate these three detrimental effects into a single radiological detriment for the purpose of evaluating the objective function.

Any comprehensive checklist of potential nonradiological risks should include detrimental health effects (i.e., illness, death, or genetic changes), adverse socioeconomic impacts, degradation in environmental quality, and public anxiety. Nonradiological risks should also include health effects from exposure to hazardous materials, which is of major concern for mixed waste. The major nonradiological risks for radioactive waste are expected to result from industrial accidents occurring during the operations phase of waste management and traffic accidents occurring during waste transpert.

Radiological risks can be divided into two categories -- public and occupational. For each of these categories, one must consider risks due to normal operations and risks due to accidents, in both the short term and the long term. For the purpose of this report, risks occurring within 100 years are considered to be short term and those occurring after 100 years are considered to be long term.

The principal normal risks are from short-term exposure of workers during waste processing, transportation, and emplacement, and long-term exposure of the general public as a result of release of radionuclides from the emplaced waste or intrusion into the waste after active institutional control of the site has been terminated. Most accidental risks occur in the short term during the operations phase and result from lowprobability abnormal events such as container rupture, waste spills, or waste fires. Accidents over the long term tend to result from unusual events that could affect the integrity of the confinement structure. 


\subsubsection{Costs}

Cost should be estimated for all waste management steps (i.e., generation, treatment, packaging, storage, transportation, and disposal). Cost estimates should include capital and operational costs for all the system components and closure and postclosure maintenance costs for the disposal facility. In addition, the time value of money and the cost of money need to be considered in these estimates. 


\section{APPLICABILITY OF THE REGINALT SYSTEM}

\subsection{REGINALT SYSTEM AS AN OVERALL ASSESSMENT TOOL FOR WASTE MANAGEMENT}

The REGINALT system was developed and is maintained by EG\&G Idaho, Inc. (1986). As a computer based decision support system designed as a tool for management of commercial low-level radioactive waste, it comprises a data base and computational models to help analyze the benefits and disadvantages of waste management alternatives. Waste management is regarded as an integrated system consisting of several steps, including generation, treatment, packaging, storage, transportation, and disposal. The alternatives for each of the steps included in REGINALT are shown in Fig. 3.

The REGINALT data base contains selected detailed information on each of the alternatives shown in Fig. 3. Information is available to assess the costs and risks of various alternatives and to establish compliance with radiation protection criteria. Information on federal and state legislative requirements for each waste management step is also given. Two types of information are available in the data base -"Publications," which contains references and abstracts of several hundred relevant publications, and "Engineering Design File," which contains detailed technical data. The technical data are available in narrative form as various descriptions and explanations and also in data tables containing relevant system parameters.

The six primary calculational models currently implemented in REGINALT represent the generation, treatment, packaging, storage, transportation, and disposal of waste. There are several secondary modules for estimating radiological risks for each of the primary models. The calculational models can use either the information provided by the data base or that supplied by the user.

The generation model can create composite waste streams for a group of states and generating sectors. Waste volumes and activities can be projected through the year 2070.

The treatment model analyzes the physical and financial effects of incineration, solidification, and compaction technologies on a series of input waste streams. The physical, chemical, and radiological characteristics of each waste stream are examined to determine environmental impact and compatibility with the treatment technology. The treatment model proceeds by converting each acceptable waste stream to its processed state by modifying the parameters (such as volume and density) affected by the conversion process. Estimates of costs and occupational radiological risks are provided.

The storage model assumes that any waste acceptable for transportation is acceptable for storage. A five-year storage period is the default period used for cost and risk estimates. Radiological waste parameters are modified as a result of radioactive decay during storage. 


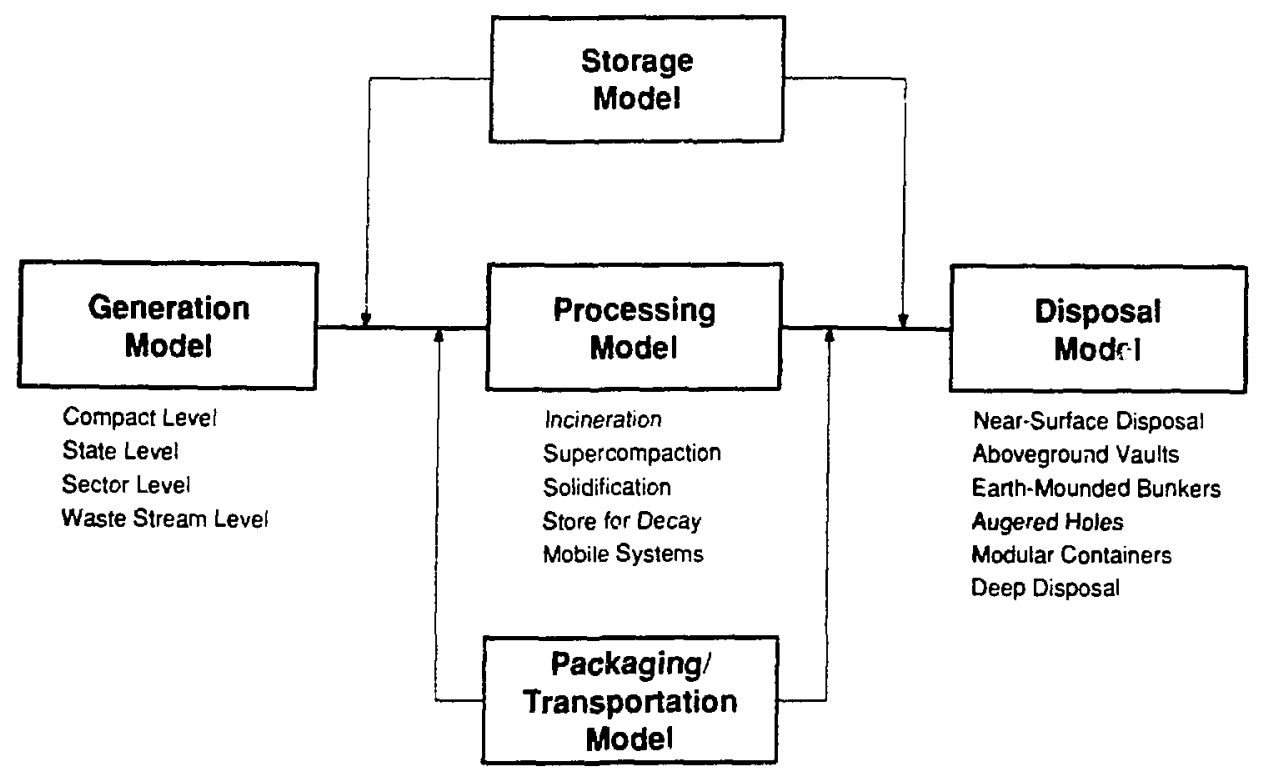

\section{FIGURE 3 REGINALT as an Integrated System (Source: Adapted} from EG\&G Idaho, Inc., 1986)

The transportation model provides the number of shipments, necessary containers, routes taken, distances and driving times, and all costs associated with the transport of waste streams for all steps of the waste management system.

The packaging model selects appropriate packaging for each waste stream from six widely used containers and three shipping casks. Included are wood and metal boxes, steel and fiber drums, and high-integrity containers and liners of stainless steel and polyethylene. Once the packaging mode is selected, REGINALT determines the quantities, costs, and appropriate added volume and weight for transportation, treatment, storage, and disposal.

The disposal model currently implements the following options: shallow land burial, enhanced shallow land burial, belowgrouild vaults, earth-mounded concrete bunkers, augered holes, aboveground vaults, and mine cavities. The model analyzes each waste stream individually as to acceptance of the selected alternative and then provides a cost estimate for the accepted waste.

The REGINALT system operates in the NOMAD2 Data Base Management System environment in which data are easily maintained and organized into groups of information of a similar nature. It is modular in design, permitting easy substitution and/or addition of new data and computational models. The system is easy to use for the nonexpert because of two sophisticated translators -- the "preprocessor" and the "postprocessor."

The preprocessor enables the user to enter the input data interactively by presenting a series of sequential input review scre ans. These screens prompt the user to specify parameters leading to specification of waste streams and waste management 
system alternatives. In most screens, all available options (e.g., treatment options) are presented, enabling the user to select the desired options simply by pressing a key. If numerical values must be specified (e.g., percentage of water in a particular waste stream), default values are presented on the screen, permitting the user to either accept the default value or to enter a user-supplied value.

The postprocessor transforms the output data into a series of formatted output reports containing information such as cost summaries for all steps of the waste management system, input data summary, and waste disposition summary. The postprocessor will probably be modified to enable generation of other types of output reports in response to the specific needs of the user.

\subsection{RECOMMENDED REGINALT MODIFICATIONS}

The REGINALT system is potentially a very useful tool for assessing the performance of DOE waste management systems. To use REGINALT for this purpose, a number of modifications will have to be made. First, the model should be tailored for the types of waste streams generated by DOE facilities. This revision should be coordinated with the revision of the DOE waste classification system (see Sec. 3.1.1). The waste streams should be described in terms of physical, chemical, and radiological parameters similar to those used by REGINALT for commercial waste streams so that an informed choice of a processing option can be made. All pertinent DOE and state regulations should also be included.

The model should enable the user to identify all feasible waste management system alternatives for a particular waste stream or a combination of waste streams. The current version of REGINALT can screen waste streams as to their suitability for particular treatment, packaging, and disposal methods. This screening procedure can easily be adapted for identifying feasible system alternatives.

The model should estimate the costs of all feasible waste management system alternatives. The economic model currently implemented on REGINALT should be revised to enable case-specific rather than generic cost estimates. The model should also incorporate the most up-to-date cost estimates such as those produced by Rogers and Associates (1987b). Model parameters common to cost and risk estimates should be checked for consistency.

The model should provide risk estimates for the feasible waste management system alternatives. It should incorporate a pathway analysis code for estimating the population dose for all system components. An accident analysis code should be incorporated for estimating the risks from exceptional events (e.g., industrial and transportation accidents) for all system components. To establish compliance with radiation protection standards for the public, a pathway analysis code should be added for estimating the radiation dose to the critical population group. Codes to estimate nonradiological risks for workers and members of the general public should be included. The occupational dose estimates should be calibrated and augmented by using monitoring data from waste management systems in current operation. Provisions should be made for using alternative models to allow improved models to be incorporated and to check on the validity of the estimates. 
Provision should be made for carrying out sensitivity analyses of the critical parameters and for estimating uncertainties for all calculations.

The model should enable the user to use the cost and risk estimates to sereen out the less desirable alternatives as described in Sec. 3.2 and shown in Fig. 1. A driver subroutine for automating this screening process should be incorporated.

Finally, the model should enable the decision maker to select trade-off factors for use with cost and risk estimates for choosing the optimal waste management system. A driver subroutine for selecting an optimal alternative from the desirable alternatives should be incorporated.

\subsection{RECOMMENDATIONS FOR THE REGINALT SYSTEMS GUIDE}

All modifications to the REGINALT system should be reflected in the REGINALT systems guide. Most organizational features of the current guide should be preserved, particularly Chapters 4 and 5 , which contain instructions for using the system and the REGINALT "walk-through." Complete documentation should be added on all the computational models used to estimate cost and risk. The documentation should be in the form of a short description and a complete list of references; enough information should be provided to enable the reader to independently reproduce any of the individual calculations. 


\section{CONCLUSION}

Although assessment of DOE waste management systems is in principle straigh1 forward, it is in fact very complex to carry out. There are several reasons for th: complexity. First, the many options available for the various waste managementsstef result in a large number of waste management system alternatives. A systemati screening procedure is needed to weed out the less desirable alternatives and to neduc the remaining alternatives to a manageable number. The REGINALT system has th capability to provide such a procedure. Second, producing reliable cost an ris estimates for the several waste management system alternatives requires using aelarg number of sophisticated computational models that may need periodic revisiod an updating. Third, large uncertainties are associated with most steps of the assestmen process, starting with the description of the waste stream at the generation ste an ending with waste disposal. It is important to provide quantitative estimates of ethes uncertainties.

Because of the complexity of the task, it is essential to have a computer whode to assist the waste management system assessor. The REGINALT computer modes wa designed for a similar task in the commercial sector. With its modular design and-data handling capabilities, REGINALT can easily be adapted to DOE waste managamen system assessment needs. 


\section{REFERENCES}

Argonne National Laboratory, 1985, Freight Network Modeling System, Volume IV: Shortest Path Analysis and Display User's Guide, ANL/ER-TM-84-1, Volume IV, April.

Armstrong, K.M., and L. Klinger, 1984, Evaluation of a Processing Technique for the Immobilization of LLRW, Monsanto Research Corporation, MLM-314S.

Arora, H., and R. Dayal, 1986, Leaching Studies of Cement Based Low Level Radioactive Waste Forms, prepared by Brookhaven National Laboratory for the U.S. Nuclear Regulatory Commission, BNL/NUREG-52026.

Blasdel, J.E., 1987, The Waste Minimization Program at the Feed Materials Production Center, Proc. Oak Ridge Model Conf., Oak Ridge, Tenn., Oct. 13-16, 1987.

Bohrer, H.A., and J.D. Dalton, 1987, Low-Level Waste Incineration Experience at the Idaho National Engineering Laboratory, Proc. 8th Annual DOE Low-Level Waste Management Forum, U.S. Department of Energy, CONF-860990, Technical Session VI, pp. 27-35.

Carter, T.J., and P.K.M. Rao, 1985, Fifteen Years of Radioactive Waste Management at Ontario Hydro, Proc. Waste Management '85, R.G. Post, ed., Tucson, Ariz., March 24-28, Vol. 2, pp. 445-451.

Cashwell, J.W., 1987, TRANSNET - A User-Accessible Network of Transportation Analysis Models, Proc. Waste Management '87, R.G. Post, ed., Tucson, Ariz., March 1-5, Vol. 1, pp. 423-426.

Dames and Moore, 1985, Final Report on Management of Low-Level Radioactive Waste in the Southeast Compact Region, Vol. I: Executive Summary; Vol. II: Management Plan; Vol. III: Siting Methodology, Pearl River, N.Y., July.

Dougherty, D.R., and P. Colombo, 1985, Leaching Mechanisms of Solidified LLW - The Literature Survey, Brookhaven National Laboratory Report, BNL-58199.

Dougherty, D.R., R.F. Pietizak, M. Fahram, and P. Colombo, 1986, Accelerated Leach Test Program, Annual Report, Brookhaven National Laboratory Report, BNL-52042.

EG\&G Idaho, Inc., 1984, Low-Level Radioactive Waste Treatment Technology, Low-Level Radioactive Waste Management Handbook Series, prepared for U.S. Department of Friergy, DOE/LLW-13Tc, July.

EG\&G Idaho, Inc., 1986, REGINALT Introductory System Guide, draft (copies can be obtained from EG\&G at P.Ó. Box 1625, Idaho Falls, ID 83415).

Emmett, R.W., 1987, Interim Storage of Low-Level Waste and the Low-Level Waste Demonstration Program, Oak Ridge Model Conf., Oak Ridge, Tenn., Feb. 3-5, pp. 249257. 
Foutes, E.C., and C.J. Queenan, III, 1987, Economic Analysis of LLW Disposal Methods, Proc. 8th Annual DOE Low-Level Waste Management Forum, U.S. Department of Energy, CONF-860990, Technical Session I, pp. 36-53.

Franz, E.M., and P. Colombo, 1985, Waste Form Evaluation Program, Brookhaven National Laboratory Report, BNL-51954.

Franz, E.M., J.H. Heiser, III, and P. Colombo, 1987, Solidification of DOE Problem Wastes, Proc. 8 th Annual DOE LoN-Level Waste Management Forum, U.S. Department of Energy, CONF-860990, Technicel Session VI, pp. 2-16.

Gilbert, T.L., N.K. Meshkov, J.P. Schubert, and L.E. Trevorrow, 1986, Planning for Greater-Confinement Disposal, Vol.II: Appendices, Low-Level Radioactive Waste Management Handbook Series, prepared by Argonne National Laboratory for U.S. Department of Energy, DOE/LLW-58T, Sept.

Gillins, R.L., and M.M. Larsen, 1987, Characterization of INEL Compactible Low-Level Wastes and Evaluation of Compactor Options, Proc. Waste Management '87, R.G. Post, ed., Tucson, Ariz., March 1-5, Vol. 3, pp. 623-629.

Greaves, J.D., 1987, A Comparative Study of Two Geometric Waste Forms - Round vs. Square, Proc. Waste Management '87, R.G. Post, ed., Tucson, Ariz., March 1-5, Vol. 3, pp. 575-579.

ICRP (International Commission on Radiological Protection), 1983, Cost-Benefit Analysis in the Optimization of Radiation Protection, Pub. 37, Annals of the 1C.RP, 10(2/3).

ICRP, 1984, A Compilation of the Major Concepts and Quantities in Use by ICRP, Pub. 42, Annals of the ICRP, 14(4).

Illinois Department of Nuclear Safety, 1986, Annual Report on the Survey of Low-Level Waste Generators in Illinois for 1984.

Johnson, T.C., K.C. Chang, T.L. Jungling, L.S. Person, C.H. Peterson, G.W. Roles, D.H. Tiktinsky, and J.C. Voglewede, 1987, Update on LLW Regulatory Guides and Topical Reports, Proc. Waste Management '87, R.G. Post, ed., Tucson, Ariz., March 1-5, Vol. 1, pp. 333-338.

Jolley, R.L., and B.R. Rogers, 1987, A Survey of Low-Level Radioactive Waste Treatment Methods and Problem Areas Associated with Commercial Nuclear Power Plants, Proc. Waste Management '87, R.G. Post, ed., Tucson, Ariz., March 1-5, Vol. 3, pp. 675-680.

Kane, M.A., 1987, Y-12 Plant Waste Minimization Strategy, Proc. Oak Ridge Model Conf., Oak Ridge, Tenn., Oct. 13-16.

Lane, D.C., and B.E. Boggs, 1987, Hazardous Waste Minimization Practices, Proc. Oak Ridge Model Conf., Oak Ridge, Tenn., Oct. 13-16. 
Logan, J.A., 1987a, DOE Systems Approach and Integration, Proc. 8th Annual DOE LowLevel Waste Management Forum, U.S. Department of Energy, CONF-860990, Technical Session VIII, pp. 1-4.

Logan, J.A., 1987b, Waste Characterization Practices, Proc. 8th Annual DOE Low-Level Waste Management Forum, U.S. Department of Energy, CONF-860990, Technical Session VI, pp. 69-73.

Lowenberg, H., and M.D. Shaw, 1987, Development of a Composite PolyethyleneFiberglass Reinforced Plastic High Integrity Container for Disposal of Low-Level Radioactive Waste, Proc. Waste Management 187, R.G. Post, ed., Tucson, Ariz., March 1-5, Vol. 3, pp. 569-574.

Maestas, E., R.G. Spaunburgh, and D.R. Leap, 1987, Low-Level Waste Treatment at the West Valley Demonstration Project, Proc. 8th Annual DOE Low-Level Waste Management Forum, U.S. Department of Energy, CONF-860990, Technical Session VI, pp. 51-63.

Malek, R.I.A., and D.M. Roy, 1987, Stability of Low Level Cement-Based Waste Systems, Proc. Waste Management '87, R.G. Post, ed., Tucson, Ariz., March 1-5, Vol. 3, pp. 363368.

Mallory, C.W., 1987, Optimization of Transportable On-Site Storage Modules, Proc. Waste Management '87, R.G. Post, ed., Tucson, Ariz., March 1-5, Vol. 3, pp. 591-596.

Mattus, A.J., and M.M. Kaczmarsky, 1987, Laboratory Performance Testing of an Extruded Bitumen Containing a Surrogate Sodium Nitrate Based, Low-Level Aqueous Waste, Proc. Waste Management '87, R.G. Post, ed., Tucson, Ariz., March 1-5, Vol. 3, pp. 517-523.

McCoy, S.B., W.M. Poplin, and T.A. Jur, 1987, A Hybrid High-Integrity Container for Disposal of Low-Level Radioactive Waste, Proc. Waste Management '87, R.G. Post, ed., Tucson, Ariz., March 1-5, Vol. 3, pp. 571-574.

Nelson, J.L., and J.R. Devine, 1980, Hanford Transuranic Storage Corrosion Review, Pacific Northwest Laboratory Report, PNL-3365.

Nielson, R.M., J.W. McConnell, Jr., and R.D. Rogers, 1987, Performance Testing of High Specific Activity Waste Forms per 10 CFR, Proc. Waste Management '87, R.G. Post, ed., Tueson, Ariz., March 1-5, Vol. 3, pp. 557-565.

Oak Ridge National Laboratory, 1984, Spent Fuel and Radioactive Waste Inventories, Projections, and Characteristics, prepared for U.S. Department of Energy, DOE/RW0006 .

Oak Ridge National Laboratory, 1986, Spent Fuel and Radioactive Waste Inventories, Projections, and Characteristics, prepared for U.S. Department of Energy, DOE/RW0006, Rev. 2. 
Okamoto, M., K. Chino, T. Baba, T. Izumida, F. Kawamura, and M. Kikuchi, 1986, Leaching Studies of Cement-Glass Package Containing Sodium Borate, Internationa] Symposium on the Scientific Basis for Nuclear Waste Management X, Materials Research Society Symposium Proceedings, Vol. 84, pp. 393-398.

Otis, M.D., 1986, Safety Assessment of Altematives to Shallow Land Burial of Low Level Radioactive Waste, Vol. 1, EG\&G Idaho, Inc., Idaho Falls, EGG-2465.

Petersson, S., and G. Hedin, 1987. The WOX Process - New Volume Reduction Technology for Reactor Waste, Proc. Waste Management '87, R.G. Post, ed., Tucson, Ariz., March 1-5, Vol. 3, pp. 665-669.

Rodgers, B.R., J.W. Wehls, Jr., A.L. Rivera, W.H. Pechin, and R.K. Genung, 1987, Waste Management Systems Model for Energy Systems Sites on the Oak Ridge Reservation, Proc. 8th Annual DOE Low-Level Waste Management Forum, U.S. Department of Energy, CONF-860990, Technical Session VI, pp. 36-50.

Rogers and Associates Engineering Corp., 1987a, Conceptual Design Report Alternative Concepts for Low-Level Radioactive Waste Disposal, prepared for EG\&G Idaho, Inc., Idaho Falls, and U.S. Department of Energy, DOE/LLW-60T.

Rogers \& Associates Engineering Corp., 1987b, Low-Level Radioactive Waste Disposal Facility Conceptual Designs, prepared for EG\&G Idaho, Inc., Idaho Falls, for the U.S. Department of Energy, RAE-8625-1.

Siskind, B., D.R. Dougherty, and D.R. MacKenzie, 1985, Extended Storage of Low-Level Radioactive Waste: Potential Problem Areas, prepared by Brookhaven National Laboratory for U.S. Nuclear Regulatory Commission, NUREG/CR-4062, Dec.

Snellman, M., and H. Uotila, 1984, Chemical Conditions in the Repository for Low- and Intermediate-Level Reactor Waste, Technical Research Laboratory of Finland, YJT84-11.

Stone \& Webster Engineering Corporation, 1985, The Analysis of Low-Level Radioactive Waste Generated in Massachusetts: Volumes, Characteristics, Projections, and Management Options, Boston, April.

Sturm, H.F., Jr., J.A. Stone, and E.L. Wilhite, 1987, Greater Confinement Disposal and Saltstone Waste Disposal Technology, Proc, 8th Annual DOE Low-Level Waste Management Forum, U.S. Department of Energy, CONF-860990, Technical Session VI, pp. 77-80.

U.S. Department of Energy, 1986, Title 49, Code of Federal Regulations, Parts 173 and 178 , revised Jan. 1 .

U.S. Nuclear Regulatory Commission, 1987, Title 10, Code of Federal Regulations, Part 71, revised Jan. 1. 
Van Kote, F., 1982, Twelve Years of Experience of Shallow Land Disposal of Low and Intermediate Level Radioactive Waste in France, Proc. Symp. on Low-Level Waste Disposal; Facility Design, Construction, and Operating Practices, M.G. Yalcintas, ed., NUREG/CP-0028, CONF-820911, Vol. 3. 